\title{
Platelet inhibition with Ticlopidine in atherosclerotic intermittent claudication
}

\author{
A AUKLAND, RA HURLOW, AJ GEORGE, J STUART \\ From the Departments of Surgery and Haematology, University of Birmingham and Queen Elizabeth \\ Hospital, Birmingham B15 2TH
}

SUMMARY Fifty-one men with atherosclerotic intermittent claudication and haemorheological abnormalities completed a double-blind, one-year randomised trial of Ticlopidine (500 mg/day), a new antiplatelet agent. Ticlopidine caused significant inhibition of platelet aggregation but did not fully correct abnormalities of coagulation, viscosity, and fibrinolysis. There was no significant improvement in walking ability, Doppler ankle-pressure indices, or calf blood flow. Sustained platelet inhibition for 12 months was insufficient to correct the prothrombotic abnormality of extensive atherosclerosis.

There is widespread interest in the use of antiplatelet agents to prevent thrombotic complications in patients with established vascular disease. Such patients, however, may have extensive atherosclerosis with associated platelet hyperactivity, hyperviscosity, an increase in coagulant proteins, and reduced fibrinolysis. ${ }^{1}$ It is unknown, moreover, whether an antiplatelet agent can be clinically effective in the presence of these multiple abnormalities of a prothrombotic nature. We have investigated this by serial study of haemostatic, haemorheological, and clinical performance tests in patients with atherosclerotic intermittent claudication randomised to take Ticlopidine or placebo for one year. This new antiplatelet agent (5-(2-chlorobenzyl)4,5,6,7-tetrahydrothieno $(3,2-\mathrm{C})$ pyridine hydrochloride) has a marked inhibitory effect on platelet activity, ${ }^{2-4}$ probably acting by stimulation of platelet membrane adenylate cyclase. ${ }^{5}$

\section{Patients and methods}

Sixty-five male outpatients (mean age $59 \mathrm{yr}$, range 40-75) with intermittent claudication for at least one year, no change in claudication distance for at least three months, no rest pain, who were not considered for arterial surgery, and who gave informed consent, were entered into the trial. On the basis of clinical examination, and arteriography in 33,16 patients had aortoiliac disease, 24 femoropopliteal disease, and 25 combined disease. Claudication was bilateral in 41 and 17 had undergone previous vas-

Accepted for publication 7 December 1981 cular reconstructive surgery. Sixteen had a history of angina or myocardial infarction. After a placebo run-in period of four weeks, patients were randomly allocated to placebo, or Ticlopidine $250 \mathrm{mg}$, twice daily for 12 months.

Resting ankle systolic pressures and pressure indices $^{6}$ were measured in both legs using a sphygmomanometer cuff and model 806-C directional Doppler (Parks Electronics Laboratory, Beaverton, USA). Exercise, to a 10 minute maximum, on a $2 \mathrm{mph}$ treadmill inclined at $10^{\circ}$ was used to determine claudication, and maximum walking, distance. An electrocardiograph-triggered strain-gauge plethysmograph (Janssen Scientific Instruments, Beerse, Belgium) was used in a $22^{\circ} \mathrm{C}$ temperaturecontrolled room to measure resting calf blood flow and the hyperaemic, or peak, flow after three minutes of thigh arterial occlusion. ${ }^{7}$

The threshold concentrations of adenosine diphosphate (ADP) and collagen required to produce a biphasic aggregation curve and maximal platelet aggregation respectively, were determined ${ }^{8}$ and $\beta$-thromboglobulin was assayed, on blood taken into EDTA-theophylline, using the kit provided by Amersham International Ltd. Thrombinclottable fibrinogen, factor VIII antigen activity (FVIII R:Ag), and euglobulin lysis time were estimated as previously described. ${ }^{18}$ Plasma viscosity at $25^{\circ} \mathrm{C}$ was measured using a Coulter-Harkness (Coulter Electronics, Luton) viscometer and whole-blood viscosity at $25^{\circ} \mathrm{C}$ and shear rates of $128 / \mathrm{s}$ and $0 \cdot 2 / \mathrm{s}$ was measured using a Contraves (Zurich) LS 30 viscometer with correction of viscosity to a standard haematocrit of $0.45 \mathrm{~V} /$. $^{9}$ 
Clinical performance tests were repeated every three months and all thrombosis tests at 0,6 and 12 months. Patient compliance was assessed by platelet ADP-aggregation every three months. Statistical significance between 0 and 12 months was determined by a two-tailed Wilcoxon signed rank test for paired data. Ankle pressure and plethysmography for the more symptomatic limb were analysed in all cases.

\section{Results}

Thirty-three men (mean age 58.6 yr) received Ticlopidine and 32 placebo (mean age $59.9 \mathrm{yr}$ ). Fourteen did not complete the study (8 Ticlopidine and 6 placebo) including four withdrawals for vascular surgery (two in each group), four defaulters, two deaths, one myocardial infarct, and three with nonthrombotic medical conditions. Side effects are shown in Table 1 . Of the 51 patients who completed the study (25 Ticlopidine, 26 placebo), 23 felt their walking had improved (11 Ticlopidine, 12 placebo), 21 were unchanged (11 Ticlopidine, 10 placebo), and 7 felt worse ( 3 Ticlopidine, 4 placebo). None of the tests of resting ankle pressure index, claudication or walking distance, or calf blood flow showed any significant improvement after 12 months of Ticlopidine (Table 2),

Ticlopidine caused significant inhibition of platelet aggregation induced by ADP and collagen (Table 3 ) but did not significantly reduce the plasma levels of $\beta$-thromboglobulin or factor VIII R:Ag. Plasma fibrinogen fell significantly but not

Table 1 Side effects reported by 65 patients

\begin{tabular}{lll}
\hline & $\begin{array}{l}\text { Ticlopidine } \\
\text { (13 patients) }\end{array}$ & $\begin{array}{l}\text { Placebo } \\
\text { (4 patients) }\end{array}$ \\
\hline Nausea/heartburn & 5 & 2 \\
Loose motions & 4 & 0 \\
Minor bruising/bleeding & 4 & 1 \\
Non-purpuric skin rash & 1 & 1 \\
Joint effusion & 1 & 0 \\
\hline
\end{tabular}

No episodes of neutropenia.

Table 2 Effect of Ticlopidine taken for 12 months on clinical performance (mean \pm SEM for 25 patients)

\begin{tabular}{lcccc}
\hline & Initial $(0$ months) & $p$ & 12 months \\
\hline $\begin{array}{l}\text { Resting pressure index } \\
\text { Claudication distance } \\
\text { (yards) }\end{array}$ & $0.55 \pm 0.02$ & NS & $0.54 \pm 0.02$ \\
$\begin{array}{l}\text { Maximum walking distance } \\
\text { (yards) }\end{array}$ & $349 \pm 35$ & NS $338 \pm 36$ \\
$\begin{array}{l}\text { Resting calf flow } \\
(\mathrm{ml} / 100 \mathrm{ml} / \mathrm{min})\end{array}$ & $6.5 \pm 0.6$ & NS & $6.4 \pm 0.7$ \\
$\begin{array}{l}\text { Peak calf flow } \\
(\mathrm{ml} / 100 \mathrm{ml} / \mathrm{min})\end{array}$ & $16.7 \pm 1.5$ & NS & $19.2 \pm 1.9$ \\
\hline
\end{tabular}

Conversion: traditional units to $S I-1$ yard $=0.9144 \mathrm{~m}$.
Table 3 Effect of Ticlopidine taken for 12 months on prothrombotic tests (mean \pm SEM for 25 patients)

\begin{tabular}{|c|c|c|c|}
\hline & Initial (0 months) & $p$ & 12 months \\
\hline $\begin{array}{l}\text { ADP aggregation } \\
(\mu \mathrm{mol} / 1)\end{array}$ & $1.54 \pm 0.31$ & $<0.001$ & $136 \cdot 10 \pm 18 \cdot 40$ \\
\hline $\begin{array}{l}\text { Collagen aggregation } \\
(\mathrm{mg} / \mathrm{l})\end{array}$ & $0.93 \pm 0.08$ & $<0.01$ & $4.30 \pm 0.60$ \\
\hline $\begin{array}{c}\beta \text {-thromboglobulin } \\
(\mu \mathrm{g} / \mathrm{l})\end{array}$ & $67 \cdot 2 \pm 8 \cdot 2$ & NS & $63 \cdot 3 \pm 8 \cdot 0$ \\
\hline $\begin{array}{l}\text { Factor VIII R:Ag } \\
\text { (units/ml) }\end{array}$ & $1.45 \pm 0.12$ & NS & $1 \cdot 75 \pm 0 \cdot 16$ \\
\hline Fibrinogen $(g / l)$ & $3.45 \pm 0.15$ & $<0.01$ & $3 \cdot 06 \pm 0.14$ \\
\hline $\begin{array}{l}\text { Euglobulin lysis time } \\
\text { (100/hours) }\end{array}$ & $27 \cdot 8 \pm 1 \cdot 5$ & $<0.05$ & $33 \cdot 1$ \\
\hline $\begin{array}{l}\text { Plasma viscosity } \\
\text { (mPa-s) } \\
\text { Whole-blood viscosity } \\
\left(25^{\circ} \mathrm{C}\right)\end{array}$ & $1.72 \pm 0.03$ & NS & $1.70 \pm 0.02$ \\
\hline $\begin{array}{cl}(\mathrm{mPa} \cdot \mathrm{s}) & -128 / \mathrm{s} \\
& -0 \cdot 2 / \mathrm{s}\end{array}$ & $\begin{array}{l}6 \cdot 50 \pm 0 \cdot 10 \\
68 \cdot 7 \pm 1 \cdot 8\end{array}$ & $\begin{array}{l}\text { NS } \\
\text { NS }\end{array}$ & $\begin{array}{l}6 \cdot 35 \pm 0 \cdot 06 \\
65 \cdot 3 \pm 1 \cdot 6\end{array}$ \\
\hline $\begin{array}{l}\text { Haematocrit }(\mathrm{ll}) \\
\text { Cholesterol }(\mathrm{mmol} / \mathrm{l})\end{array}$ & $\begin{array}{l}0.42 \pm 0.04 \\
6.18 \pm 0.22\end{array}$ & $\begin{array}{l}\text { NS } \\
<0.01\end{array}$ & $\begin{array}{l}0.41 \pm 0.04 \\
6.72 \pm 0.26\end{array}$ \\
\hline
\end{tabular}

sufficiently to reduce plasma viscosity or wholeblood viscosity significantly. The euglobulin lysis time improved significantly in the treatment group but a similar significant $(\mathrm{p}<0.05)$ improvement, from 31.4 to 35.8100 /hours, also occurred in the placebo group. Patients taking Ticlopidine showed a significant rise in serum total cholesterol during the 12 month period (Table 3 ).

With the exception of the improvement in euglobulin lysis time, none of the clinical performance (Table 2) or laboratory (Table 3 ) tests showed a significant improvement over 12 months in the 26 patients on placebo. There was also no significant change in smoking habit in either the treatment or placebo group.

\section{Discussion}

The rationale for antiplatelet therapy as prophylaxis against recurrence of myocardial infarction, transient cerebral ischaemic attacks, or other clinical presentations of degenerative vascular disease, is that the platelet role is a predominant one. Even if platelet hyperactivity cannot be demonstrated in an individual patient, it is argued, drug-induced hypoactivity may be beneficial. This hypothesis is less secure if other haemostatic and haemorheological abnormalities of a prothrombotic nature coexist and remain unaltered by platelet inhibition. Platelet hyperactivity, ${ }^{10-13}$ hyperfibrinogenaemia and hyperviscosity, ${ }^{814}$ and reduced fibrinolytic activity ${ }^{15-17}$ have all been described in atherosclerosis, including a study of 37 of the 65 patients entered into the present trial.' ${ }^{\prime}$ Moreover, it is uncertain whether 
these prothrombotic abnormalities are of aetiological significance ${ }^{18}$ or collectively represent a nonspecific stress response to established vascular disease. ${ }^{\prime}$

Effective long-term inhibition of platelet deposition on damaged endothelium might simultaneously reduce fibrin deposition so that liver synthesis of coagulant proteins could be reset at a lower level. Since fibrinogen is a major determinant of both plasma viscosity and whole-blood viscosity ${ }^{1920}$ this might be of rheological as well as haemostatic benefit. Inhibition of platelet aggregation in severe atherosclerosis might also increase distal limb perfusion so that a larger area of undamaged endothelium would be available to release fibrinolytic activator. Although Ticlopidine caused sustained inhibition of platelet aggregation and a significant fall in fibrinogen concentration, it did not significantly lower plasma- or blood-viscosity, did not reduce the activity of factor VIII R:Ag, and was not associated with increased endothelial cell production of plasminogen activator to a greater extent than placebo. Thus the prothrombotic tendency of our atherosclerotic patients was not fully corrected. In addition, there was no subjective or objective evidence of clinical benefit although the number of patients studied was small. Two recent reports ${ }^{2122}$ suggested that, because of a tendency to spontaneous improvement in younger claudicants, the benefit of drug therapy may be evident only in patients over $60 \mathrm{yr}$ when the disease is relatively static, but no selective clinical benefit was found in our oldest patients. Analysis of the data for all patients at six months showed a statistically significant improvement in peak calf blood flow, ${ }^{23}$ particularly in those under $60 \mathrm{yr}$, but the difference was no longer significant at 12 months.

Although Ticlopidine, given for 12 months, did not fully correct the prothrombotic abnormality of patients with extensive atherosclerosis, this result should not be extrapolated to other antithrombotic agents or to patients with less extensive vascular disease. A significant reduction in plasma fibrinogen, which is a major determinant of blood viscosity, is an interesting aspect of Ticlopidine's action which was also noted after four and 12 months' treatment in 41 patients with cerebrovascular ischaemia. ${ }^{24}$ Failure of antiplatelet agents to achieve clinical benefit in drug-intervention trials in vascular disease may, however, reflect their limited antithrombotic spectrum and the persistence of other prothrombotic abnormalities.

We are indebted to Professor F Ashton and Professor G Slaney for providing facilities and referring patients to the study; Dr RC Cotton and the Phar- maceuticals Division, ICI Ltd for a research grant; $\mathrm{Mr}$ BJ Middleton for statistical advice; the Haematology Department, Birmingham General Hospital for $\beta$-thromboglobulin assays; and Mrs $P$ Elton, Mrs D Hughes, and Mr GR Vaughan for technical assistance.

\section{References}

' Stuart J, George AJ, Davies AJ, Aukland A, Hurlow RA Haematological stress syndrome in atherosclerosis. $J$ Clin Pathol 1981;34:464-7.

${ }^{2}$ Thebault JJ, Blatrix GE, Blanchard JF, Panak EA. Effects of Ticlopidine, a new platelet aggregation inhibitor in man. Clin Pharmacol Ther 1975;18:485-90.

${ }^{3}$ O'Brien JR, Etherington MD, Shuttleworth RD. Ticlopidine: an antiplatelet drug; effects in human volunteers. Thromb Res 1978;13:245-54.

${ }^{4}$ Knudsen JB, Gormsen J. The effect of Ticlopidine on platelet function in normal volunteers and in patients with platelet hyperaggregability in vitro. Thromb Res 1979;16:663-71.

$s$ Ashida S, Abiko Y. Mode of action of Ticlopidine in inhibition of platelet aggregation in the rat. Thromb Haemost 1979;41:436-49.

- Yao ST, Hobbs JT, Irvine WT. Ankle systolic pressure measurements in arterial disease affecting the lower extremities. $\mathrm{Br}$ J Surg 1969;56:676-9.

${ }^{7}$ Hurlow RA, Hardman J. ECG-triggered strain gauge plethysmography. In: Beard RN, Woodcock J, eds. Diagnosis and monitoring in arterial surgery. Bristol: John Wright, 1980:21-8.

${ }^{8}$ Blunt RJ, George AJ, Hurlow RA, Strachan CJL, Stuart J. Hyperviscosity and thrombotic changes in idiopathic and secondary Raynaud's syndrome. Br J Haematol 1980;45:651-8.

${ }^{9}$ Inglis TCMcN, Carson PJ, Stuart J. Clinical measurement of whole-blood viscosity at low-shear rates. Clin Hemorheol 1981;1:167-77.

${ }^{10}$ Murphy EA, Mustard JF. Coagulation tests and platelet economy in atherosclerotic and control subjects. Circulation 1962;25:114-25.

"O'Brien JR, Etherington MD, Jamieson S, Lawford P, Lincoln $\mathrm{SV}$, Alkjaersig NJ. Blood changes in atherosclerosis and long after myocardial infarction and venous thrombosis. Thromb Haemost 1975;34:483-97.

12 Ward AS, Porter N, Preston FE, Morris-Jones W. Platelet aggregation in patients with peripheral vascular disease. Atherosclerosis 1978;29:63-8.

${ }^{13}$ Cella G, Zahavi J, de Haas HA, Kakkar VV. $\beta$-thromboglobulin, platelet production time and platelet function in vascular disease. Br J Haematol 1979;43:127-36.

14 Dormandy JA, Hoare E, Colley J, Arrowsmith DE, Dormandy TL. Clinical, haemodynamic, rheological, and biochemical findings in 126 patients with intermittent claudication. $\mathrm{Br} \mathrm{Med}$ J 1973;iv:576-81.

is Nestel PJ. Fibrinolytic activity of the blood in intermittent claudication. Lancet 1959;ii:373-5.

${ }^{10}$ Naimi S, Goldstein R, Proger S. Studies of coagulation and fibrinolysis of the arterial and venous blood in normal subjects and patients with atherosclerosis. Circulation 1963;27:904 18.

${ }^{17}$ Browse NL, Gray L, Jarrett PEM, Morland M. Blood and veinwall fibrinolytic activity in health and vascular disease. $\mathrm{Br} \mathrm{Med}$ J 1977;i:478-81

${ }^{18}$ Meade TW, North WRS, Chakrabarti R, Stirling Y, Haines AP, Thompson SG, Brozovic $M$. Haemostatic function and cardiovascular death: early results of a prospective study. Lancet 1980;i:1050-4. 
${ }^{19}$ Hutchinson RM, Eastham RD. A comparison of the erythrocyte sedimentation rate and plasma viscosity in detecting changes in plasma proteins. J Clin Pathol 1977;30:345-9.

${ }^{20}$ Stuart J, Kenny MW. Blood rheology. J Clin Pathol 1980;33:417-29.

${ }^{21}$ Clyne CAC, Galland RB, Fox MJ, Gustave R, Jantet GH, Jamieson CW. A controlled trial of naftidrofunyl (Praxilene) in the treatment of intermittent claudication. $\mathrm{Br} J$ Surg 1980;67:347-8.

${ }^{22}$ Waters KJ, Craxford AD, Chamberlain J. The effect of naftidrofunyl (Praxilene) on intermittent claudication. Br J Surg 1980;67:349-51.
${ }^{23}$ Aukland A, Stuart J, Hurlow RA, George AJ, Davies AJ. A new antiplatelet agent: Ticlopidine. Br J Surg 1981;68:807.

${ }^{24}$ Conard J, Lecrubier C, Scarabin PY, Horellou MH, Samama M. Bousser MG. Effects of long term administration of Ticlopidine on platelet function and hemostatic variables. Thromb Res 1980;20:143-8.

Requests for reprints to: Professor J Stuart, Department of Haematology, Medical School, University of Birmingham, Birmingham B15 2TJ, England. 